\section{PP-277排尿筋過反射収縮不全と考えられた症例 に対する治療経験}

\section{岡山赤十字病院 \\ 大橋 輝久, 野崎 邦浩, 竹中 皇, 近藤 捷嘉}

【目的】過活動膀腅の辺縁疾患として排尿筋過反射収維不全 (DHIC)が挙げられるが, この DHICに対する治療法は現在 まで確立されていない。今回我々は薬物療法の有用性につ いて若干の知見を得たので報告する。対象並びに方法】症 例は 42 例であり，男性 18 例，女性 24 例で，年齢は $53 \sim 90$ 歳である。超音波検查および尿道内圧測定, 圧尿流測定検査 を含む尿流動態検査にて，下部尿路通過障害がなく，無抑制 収縮および残尿 (50 $\mathrm{ml}$ 以上あるいは残尿率 $30 \%$ 以上)を認 めるものを対象とした。結果】主たる排尿症状は頻尿 12 例，尿失禁 19 例，排尿困難 8 例，尿意切迫 3 例であった。 尿流動態検查所見は過活動膀胱に比較して著変は認められ なかった。治療法に関し， ウラピジルを中心とした， $\alpha-1$ 遮断剂単独が 17 例, 抗コリン剂併用が 24 例, 抗コリン郕単 独が 1 例であった。エンドポイント（3～83 ケ月，中央值 18 ヶ月）の改善率は各々 $76.5 \%$ (13/17 例), $58.3 \%$ (14/24 例), $0 \%(0 / 1$ 例)で, 42 例中 27 例と $64.3 \%$ の改善を得た。 【結論】今回の成績より，排尿筋過反射収縮不全を示す高齢 者は ADL の低下した症例が多いため, $\alpha-1$ 遮断剂で残尿を 減少させ, 1 回排尿量の増加を目的とし, さらに夜間に少量 の抗コリン剤を併用し，夜間頻尿および失禁の改善をはか ることが患者の QOL 向上に有用であることが示唆された。

\section{PP-278 睡眠障害と下部尿路症状の関連について}

\section{日本大学医学部泌尿器科学}

杉本 周路, 増子 亜耶, 井門 祐一郎, 長谷川了, 大日方 大亮, 吉澤 剛, 長根 裕介, 佐藤 克彦, 持田 淳一, 一瀬 岳人, 平野 大作, 高橋 悟, 三好 みどり

【目的】当院の泌尿器科を受診した新患に対して、診察時に国際前立腺 症状スコア (IPSS)、ピッッバーグ睡眠質問票 (PSQI)、過活動膀胱症 状質問票 (OABSS)を調查した。また尿流量測定や残尿測定を行い、睡 眠障害と下部尿路症状の関連性について検討した。対象】2007年 10 月 1 日から 2008 年 2 月 14 日までに日本大学板橋病院泌尿器科を受診 した新患 519 例、男性 314 例、女性 205 例を対象とした。平均年龄は 57.4 藏であった。結果IIPSS と PSQI には相関が認められ、軽症に対して中 等症、重症で有意に PSQIが高かった $(\mathrm{p}<0.0001)$ 。IPSS 各項目では、 症状あれば有意にPSQIが高かった（蓄尿症状 $\mathrm{p}=0.0181$ ，排尿症状 $\mathrm{p}<$ $0.0001 ） 。 さ ら に$ 夜間排尿回数と PSQIに相関が認奶られ、夜間排尿回 数と「睡眠困難」が最も相関した $(\mathrm{p}<0.0001)$ 。QOLの $5 \sim 6$ 点 (重症)

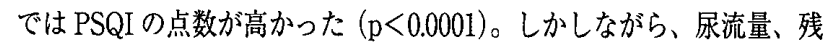
尿量はPSQI との相関が認められなかった。 OABSS と PSQIに相関が 認められ、OABSS で診断基準を満たす OAB 群では non OAB 群に比 へ、有意に PSQI が高かった $(\mathrm{p}=0.0013)$ 。考察]諸家の報告と同様に、 前立腺肥大症などの泌尿器科疾患に起因する夜間頻尿（夜間排尿回数 の增加)は睡眠障害にかなりの影響をおよぼしていた。また、女性では $O A B$ 症状が睡眠障害にかなり影響することが示唆された。

\section{PP-279 過活動傽胱に対する第二世代抗コリン剤 交代療法の有用性の検討}

\section{山田赤十字病院泌尿器科 \\ 大西 毅尚, 加藤 学, 保科 彰}

【目的】過活動膀胱 (OAB) に対する第二世代抗コリン剤の 使用法として、 first line または second line でコハク酸ソリ フェナシンが投与された症例のうち、症状不変、または副 作用出現例に対してイミダフェナシンに変更した場合の有 効性、安全性について検討した。対象と方法】OAB の診断 で、 first line または second line としてソリフェナシンを投 与された 45 例のうちソリフェナシン投与にて効果不十分、 または口渴が出現した 18 例に対して、イミダフェナシン投 与に変更し、有効性および副作用改善度について検討を 行った【結果】ソリフェナシンよりイミダフェナシンへの 切り替光症例のうち症状が悪化したため投与中止したもの が 1 例にみられたが IPSS の変化に関して統計学的有意差 は認められなかった。副作用に関しては 1 例のみ口渴が增 強したため投与中止となったが、イミダフェナシンへの変 更によって有意に副作用の改善がみられた。さらにQOL スコアに関しても有意な QOL の改善は見られなかったも のの改善傾向がみられた。結論】副作用出現によるソリ フェナシン投与継続困難症例に対して、イミダフェナシン へ切り替えることで効果の減弱をきたすことなく副作用の 軽隇が得られる可能性が示唆された。

\section{PP-280}

\section{夜間頻尿を訴える外来患者における睡眠 時無呼吸症候群の頻度と持続陽圧呼吸療 法による効果}

\section{東京撆察病院泌尿器科"), 東京大学泌尿器科2) \\ 宮蓄 英世 ${ }^{1}$, 小串 哲生 ${ }^{11}$, 宗像 昭夫 ${ }^{13}$, 松島 常1), 本間 之夫2)}

背景と目的：泌尿器科外来において夜間頻尿を訴える患者 には、泌尿器疾患が原因であるもののほかに睡眠時無呼吸症 候群（SAS）による夜間多尿の患者が含まれていると考えら れる。今回我々は当科に通院する夜間頻尿を訴える外来患者 にどの程度の SAS 患者が存在するのか、また持続陽圧呼吸 療法（CPAP）によりどの程度夜間頻尿が改善するのかにつ いて検討した。対象と方法：対象は当科外来に通院中の夜間 頻尿 (夜間排尿回数が一晚 2 回以上) を訴えた患者 35 人。そ のうち実際に当院耳鼻科を受診し、SASの検查を受けたの は 20 名 (平均 $73.7 \pm 7.52$ 歳、男性 19 人、女性 1 人)であった。 そのうち SAS と診断されたのは 15 名 (75\%)、CPAP の適応 であったのは 10 名 $(50 \%)$ であった。実際に CPAP 治療を 導入された 8 名 $(40 \%)$ の夜間排尿回数は、 $3.88 \pm 0.64$ 回から $1.88 \pm 0.64$ 回に減少した。結論：夜間頻尿を訴える当院泌尿 器科外来患者にはSAS 患者が高率に認められ、CPAP 治療 の適応となる重症のSAS 患者が多く認められた。また CPAP 治療の導入により、そのほとんどの患者で夜間排尿回 数が減少した。夜間頻尿を訴える患者の問診時には常に SAS の可能性を念頭におく必要があると考えられる。 